\title{
PROFESIONALISME PEMANDU DALAM MENINGKATKAN PELAYANAN KUNJUNGAN ISTURA PADA ISTANA KEPRESIDENAN TAMPAKSIRING BALI
}

\author{
Oleh: \\ Dewa Gede Putra Arimbawa \\ Istana Kepresidenan Tampaksiring Bali \\ Email : dewagdeputraa@gmail.com
}

\begin{abstract}
Drofesionalisme sangat ditentukan oleh kemampuan seseorang atau individu dalam melakukan suatu pekerjaan menurut bidang tugas dan tingkatannya masing-masing. Hasil dari pekerjaan itu lebih ditinjau dari segi sesuai porsi, objek, bersifat terus menerus dalam situasi dan kondisi yang bagaimanapun serta jangka waktu penyelesaian pekerjaan yang relatif singkat. Dalam penelitian ini menggunakan metode deskriptif kualitatif. Teori yang digunakan dalam penelitian ini adalah Teori Parasuraman (2001) yang menyatakan 5 indikator pelayanan yaitu bukti fisik, keandalan, daya tanggap, jaminan dan empati.

Hasil penelitian menunjukkan bahwa Profesionalisme pemandu dalam meningkatkan pelayanan kunjungan istura pada Istana Kepresidenan Tampaksiring Bali telah berjalan dengan baik sesuai dengan hasil analisis menggunakan Teori Pelayanan. Tetapi masih perlu dilakukan beberapa evaluasi, hal itu karena dari 5 indikator terdapat 1 indikator pelayanan yang harus dievaluasi yaitu perlunya penambahan sarana kebersihan sehingga tidak mengganggu kebersihan sebagai salah satu bentuk pendukung pelayanan. Sedangkan 4 indikator yang telah memenuhi yaitu adanya pemandu yang telah memiliki keterampilan dalam memandu, memandu dengan baik sehingga mudah dimengerti, memberikan kesempatan kepada pengunjung untuk bertanya serta memperhatikan kebutuhan informasi dari pengunjung. Kendala dari profesionalisme pemandu dalam meningkatkan pelayanan kunjungan istura pada Istana Kepresidenan Tampaksiring Bali adalah masih kurangnya jumlah pemandu dan masih kurangnya kemampuan pemandu dalam berbahasa asing.
\end{abstract}

Kata Kunci : Profesionalisme, Pelayanan, Kunjungan Istura

$P$ rofessionalism is very much determined by the ability of a person or individual to do a job according to their respective duties and levels. The results of the work are more viewed in terms of appropriate portions, objects, are continuous in any situation and condition as well as a relatively short period of completion of the work. In this study using a qualitative descriptive method. The theory used in this research is Parasuraman theory (2001) which states 5 indicators of service, namely physical evidence, reliability, responsiveness, assurance and empathy.

The results showed that the professionalism of the guides in improving istura visit services at the Tampaksiring Presidential Palace in Bali has gone well in accordance with the results of the analysis using the Service Theory. However, some evaluation still needs to be done, this is because of the 5 indicators there is 1 service indicator that must be evaluated, namely the need to add cleanliness facilities so that it does not interfere with cleanliness as a form of service support. Meanwhile, the 4 indicators that have met are the presence of guides who have skills in guiding, guiding well so that it is easy to understand, giving visitors the opportunity to ask questions and paying attention to the information needs of visitors. The obstacle from the professionalism of the guides in improving the istura visit service at the Tampaksiring Bati Presidential Palace is the lack of the number of guides and the lack of the ability of guides in foreign languages.

Keywords: Professionalism, Service, Istura Visit

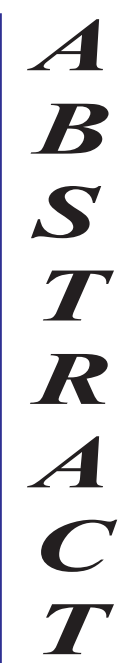




\section{A. PENDAHULUAN}

Sumber daya manusia merupakan faktor terpenting dalam setiap kegiatan perusahaan karena bagaimanapun canggihnya teknologi yang digunakan tanpa didukung oleh manusia sebagai pelaksana kegiatan operasional tidak akan mampu menghasilkan output yang sesuai dengan tingkat efisiensi yang diharapkan. Peran sumber daya manusia dalam organisasi sebenarnya sudah ada saat dikenalnya organisasi sebagai wadah usaha bersama dalam mencapai suatu tujuan. Adanya berbagai karakter sumber daya manusia sebagai karyawan dalam suatu perusahaan atau organisasi dengan adanya perbedaan latar belakang yang dimiliki seperti perbedaan pengalaman, pendidikan, ekonomi, status kebutuhan, harapan menuntut pimpinan perusahaan untuk dapat mengelola dan memanfaatkan sehingga tidak menghambat tujuan organisasi yang ingin dicapai (Hasugian, 2017).

Kinerja pelayanan yang baik membutuhkan adanya profesionalisme dalam bekerja dan komunikasi yang baik. Kurniawan (2005:73), mengemukakan "Profesionalisme adalah suatu kemampuan dan ketrampilan seseorang dalam melakukan pekerjaan menurut bidang dan tingkatan masing-masing. Profesionalisme menyangkut kecocokan (fitness) antara kemampuan yang dimiliki birokrasi (bureaucratic competence) dengan kebutuhan tugas (task-requiretmen) Profesionalisme sangat ditentukan oleh kemampuan seseorang atau individu dalam melakukan suatu pekerjaan menurut bidang tugas dan tingkatannya masing-masing. Hasil dari pekerjaan itu lebih ditinjau dari segi sesuai porsi, objek, bersifat terus menerus dalam situasi dan kondisi yang bagaimanapun serta jangka waktu penyelesaian pekerjaan yang relatif singkat (Almasdi, 2000:99).

Istana Kepresidenan Tampaksiring Bali merupakan salah satu obyek sejarah yang berda di Kabupaten Gianyar dan digunakan untuk aktivitas pemerintahan. Semakin banyak kunjungan masyarakat umum dapat meningkatkan pengetahuan masyarakat mengenai sejarah pemerintahan. Maka dari itu, setiap pegawai dituntut untuk bekerja secara profesional memberikan informasi mengenai Istana Kepresidenan Tampaksiring Bali. Pemberian pelayanan yang baik kepada masyarakat umum yang berkunjung ke Istana Kepresidenan Tampaksiring akan menciptakan kepuasan pengunjung. Apabila konsumen merasa puas, mereka akan melakukan kunjungan ulang dan merekomendasikan kepada orang lain untukberkunjung ke Istana Kepresidenan Tampaksiring Bali. Oleh sebab itu Istana Kepresidenan Tampaksiring Bali harus mulai memikirkan pentingnya pelayanan pengunjung secara lebih matang melalui kualitas pelayanan, karena semakin disadari kini pelayanan merupakan aspek vital dalam rangka mengenalkan sejarah kepemerintahan (Tjiptono, 2004:145).

Saat ini Istana Kepresidenan Tampaksiring Bali telah memiliki sistem pendaftaran online yang dikenal dengan SPION yaitu Sistem Informasi Pendaftaran Online jika akan berkunjung ke 
Istana Kepresidenan Tampaksiring Bali. Adanya website resmi ini membuka peluang bagi masyarakat umum untuk berkunjung ke Istana Kepresidenan Tampaksiring Bali dan mengetahui sejarah kepemerintahan. Setiap kunjungan dapat dilakukan secara rombongan dan mengisi formulir pendaftaran secara online serta harus menyertakan syarat atau ketentuan yang harus dipenuhi. Karena adanya inovasi pendaftaran online ini, Istana Kepresidenan Tampaksiring Bali memproleh penghargaan oleh Menteri Sekretaris Negara yang diberikan kepada Istana Kepresidenan Tampaksiring Bali Sekretariat Presiden sebagai penerima anugerah inovasi di bidang Pelayanan Eksternal atas Inovasi Pendaftaran Kunjungan Masyarakat Online pada tanggal 10 April 2018. Hal ini menunjukkan bahwa Istana Kepresidenan Tampaksiring Bali selalu berinovasi memberikan pelayanan kepada masyarakat umum.

Data kunjungan istura selama 3 (tiga) tahun yaitu tahun 2016-2018 mengalami fluktuasi setiap tahunnya. Penggunaan website atau permohonan kunjungan secara online mampu mendorong peningkatan kunjungan istura. Seperti pada tahun 2016, jumlah kunjungan istura sebanyak 642 rombongan yang terdiri dari 108.734 orang tetapi mengalami penurunan di tahun 2017 dengan kunjungan istura sebanyak 330 rombongan atau 60.876 orang. Penurunan jumlah kunjungan istura pada tahun 2017 disebabkan karena adanya renovasi gedung dan halaman pada Istana Kepresidenan Tampaksiring Bali sehingga kegiatan istura ditutup sementara waktu pada tahun 2017. Maka dari itu, pada tahun 2018, kegiatan kunjungan istura kembali dibuka dan mengalami peningkatan sebanyak 396 rombongan yang terdiri dari 733.393 orang dengan memanfaatkan inovasi baru yaitu permohonan kunjungan yang dilakukan secara online melalui website resmi Istana Kepresidenan Tampaksiring Bali. Selain karena peran pemanfaatan teknologi informasi yaitu penggunaan website atau pengajuan permohonan kunjungan secara online, komunikasi dan profesionalisme memiliki peran penting dalam pelayanan kunjungan istura. Bekerja secara profesional dan mampu berkomunikasi dengan baik kepada sesama pegawai/karyawan dan dengan pengunjung mampu meningkatkan rasa nyaman dan aman serta memberikan kepuasan tersendiri bagi pengunjung. Jumlah pemandu mengalami peningkatan setiap tahunnya tetapi jumlah pelayanan yang diberikan mengalami fluktuasi selama tahun 2016-2018. Jumlah pelayanan terendah yaitu tahun 2017 yang artinya semenjang inovasi pendaftaran online dimulai, pemandu tidak bekerja secara maksimal sehingga menunjukkan penurunan profesionalime pemandu dalam bekerja.

Berdasarkan uraian dan permasalahan di atas, maka peneliti ingin menganalisis lebih dalam terkait dengan peranan profesionalisme dan komunikasi dalam meningkatkan pelayanan kunjungan istura pada Istana Kepresidenan Tampaksiring Bali Adapun judul penelitian yang diajukan adalah "Profesionalisme Pemandu Dalam Meningkatkan Kunjungan Istura Pada Istana Kepresiden 


\section{Tampaksiring Bali”.}

\section{B. METODE}

Bentuk penelitian dalam penelitian ini adalah penelitian deskriptif yaitu penelitian yang dilakukan untuk mengetahui nilai baik satu variabel atau lebih (independent) tanpa membuat pembandingan atau hubungan dengan variabel lain. Penelitian ini dilaksanakan Kementrian Sekretariat Negara Republik Indonesia Sekretariat Presiden Istana Kepresidenan Tampaksiring Bali Kabupaten Gianyar Provinsi Bali yang berlokasi di Jalan Raya Dr Ir Soekarno Tampaksiring. Pemilihan Istana Kepresidenan Tampaksiring Bali sebagai tempat penelitian karena merupakan salah satu istana yang memiliki jumlah kunjungan terbanyak dengan adanya sistem permohonan kunjungan secara online yang disertai dengan jumlah pemandu yang memadai.

Dalam penelitian ini, jenis data yang digunakan adalah data kualitatif dan data kuantitatif. Sedangkan berdasarkan sumber datanya dibedakan menjadi data primer dan data sekunder. Dalam penelitian ini instrumen yang digunakan untuk mengumpulkan data mengenai profesionalisme pemandu dalam meningkatkan pelayanan kunjungan istura pada Istana Kepresidenan Tampaksiring Baliadalah peneliti itu sendiri. Instrumen utama dalam penelitian ini adalah peneliti itu sendiri. Selain itu peneliti dibantu dengan pedoman wawancara sebagai instrumen utama dalam pengumpulan data.

\section{HASIL DAN PEMBAHASAN}

\section{a). Profesionalisme Pemandu Dalam Meningkatkan Pelayanan Kunjungan Istura Pada Istana Kepresidenan Tampaksiring Bali.}

Profesional adalah sebagai suatu kemampuan dan keterampilan seseorang dalam melakukan pekerjaan menurut bidang dan tingkatan masing-masing. profesionalisme menyangkut kecocokan (fitness) antara kemampuan yang dimiliki oleh birokrasi (bureaucratic competence) dengan kebutuhan tugas (task-requirement). Seorang pemandu harus memiliki profesionalisme dalam bekerja sehingga tidak menimbulkan adanya informasi negatif atau memunculkan persepsi negatif dari pengunjung. Seorang pemandu yang memiliki profesionalisme kerja ditunjukkan dari kemampuan dan keterampilan pemandu dalam melaksanakan tugas sesuai dengan bidang dan tingkatan masing-masing secara tepat waktu dan cermat. Tugas pemandu berdasarkan Keputusan Kepala Istana Kepresidenan Tampaksiring Bali Nomor 5 Tahun 2020 adalah menjelaskan kepada pengunjung mengenai obyek-obyek di Istana Kepresidenan Tampaksiring Bali dan mengarahkan pengunjung mengikuti rute yang telah ditentukan.

Jumlah pemandu pada Istana Kepresidenan Tampaksiring Bali berdasarkan Keputusan Kepala Istana Kepresidenan Tampaksiring Bali Nomor 5 Tahun 2020 adalah sebanyak 26 pemandu 
yang diprioritaskan staf dari subbagian rumah tangga dan protokol (penata jamuan) akan tetapi jika pengunjung melebihi kapasitas maka akan dibantu oleh stag subbagian lainn seperti subbagian tata usaha, subbagian perlengkapan dan sub bagian bangunan. Jumlah pemandu adalah sebanyak 26 orang dan semuanya berasal dari pegawai Istana Kepresidenan Tampaksiring Bali.

Untuk melaksanakan tugasnya, seorang pemandu harus bersikap profesional dalam bekerja. Profesionalisme menyangkut kecocokan antara kemampuan yang dimiliki oleh birokrasi dengan kebutuhan tugas.artinya keahlian yang dimiliki dan kemampuan aparat merefleksikan arah dan tujuan yang ingin dicapai oleh organisasi.

Siagian (2000:163) menyatakan bahwa "Profesionalisme adalah keandalan dalam pelaksanaan tugas sehingga terlaksana dengan mutu tinggi, waktu yang tepat, cermat, dan dengan prosedur yang mudah dipahami dan diikuti oleh pelanggan". Seorang pemandu harus memiliki profesionalisme dalam bekerja sehingga tidak menimbulkan adanya informasi negatif atau memunculkan persepsi negatif dari pengunjung. Pemandu adalah seseorang atau sekelompok orang yang bertugas menemani, mengantar, memberikan informasi dan saran kepada seorang atau sekelompok wisatawan yang sedang melakukan kunjungan ke suatu tempat (Irawati, 2013:20). Maka dari itu dibutuhjan adanya pemandu yang dapat bekerja secara profesional.

Seorang pemandu yang memiliki profesionalisme kerja ditunjukkan dari kemampuan dan keterampilan pemandu dalam melaksanakan tugas sesuai dengan bidang dan tingkatan masingmasing secara tepat waktu dan cermat. Profesionalisme pemandu dalam meningkatkan pelayanan kunjungan Istura di Istana Kepresidenan Tampaksiring ditunjukkan dengan adanya bukti fisik, kehandalan, ketanggapan, jaminan dan empati. Adapun profesionalisme pemandu dalam meningkatkan pelayanan kunjungan istura pada Istana Kepresidenan Tampaksiring Bali dianalisis dengan menggunakan Teori Pelayanan yang dapat dijabarkan sebagai berikut :

\section{a. Tangible (Bukti Langsung)}

Tangible (bukti langsung) yaitu kemampuan dari Istana Kepresidenan Tampaksiring Bali dalam memberikan pelayanan. Penampilan dan kemampuan ini ditunjukkan dengan sarana dan prasarana yang dimiliki oleh Istana Kepresidenan Tampaksiring Bali dalam mendukung pelayanan. Sarana dan prasarana tersebut misalkan tempat beristirahat yang sudah disediakan wantilan, tempat informasi yang berada di bagian depan di bagian loket informasi, disediakan pemandu yang nantinya akan memberikan informasi kepada pengunjung, tempat makan, tempat membeli souvenir dan berbagai sarana pendukung lainnya.

Sarana dan prasarana yang disediakan oleh Istana Kepresidenan Tampaksiring Bali masih perlu dilakukan evaluasi dan penambahan sarana kebersihan seperti tempat sampah di lokasi strategis. 
Hal ini dilakukan untuk mencegah pengunjung membuang sampah sembarangan dan tetap menjaga kebersihan Istana Kepresidenan Tampaksiring Bali. Istana Kepresidenan Tampaksiring Bali dapat menambah jumlah tempat sampah dan mengatur penempatan yang dapat dengan mudah dijangkau pengunjung dan tidak mengganggu pemandangan obyek kunjungan.

\section{b. Reliability (Keandalan)}

Kelengkapan sarana dan prasarana menjadi salah satu faktor penting yang mempengaruhi kepuasan pengunjung. Selain itu dibutuhkan adanya Reliability (keandalan) yaitu kemampuan dari pemandu dalam memberikan pelayanan kepada pengunjung Istana Kepresidenan Tampaksiring Bali. Pemberian pelayanan ditunjukkan dari profesionalisme pemandu dalam memberikan informasi yang berkaitan dengan Istana Kepresidenan Tampaksiring Bali sehingga tidak memberikan persepsi negatifatau kesalahan informasi.

Pemandu telah bekerja dengan profesional yaitu memberikan informasi tentang Istana Kepresidenan Tampaksiring Bali dengan jelas sehingga tidak menimbulkan persepsi negatif. Tetapi dalam hal penyampaiannya masih harus dilakukan evaluasi karena dalam penyampaiannya terlalu cepat sehingga pengunjung meminta pemandu untuk mengulangi dalam penyampaian informasi. Hal ini dapat diatasi dengan memberikan pendidikan dan pelatihan bagi pemandu sehingga mampu menambah keterampilan dan keahlian dalam bekerja.

\section{c. Responsiveness (Daya Tangkap)}

Adanya timbal balik antara pemandu dengan pengunjung yang disebut dengan daya tangkap (responsiveness). Daya tangkap diukur dari kualitas pelayanan yang diberikan, apakah telah sesuai dengan harapan pengunjung dalam hal pemberian informasi. Informasi yang disampaikan oleh pemandu telah sesuai dengan harapan dan pemandu telah bekerja secara profesional. Pemandu juga memberikan kesempatan kepada pengunjung untuk bertanya, menyampaikan keluhan, kritik dan saran sebagai respon balik atas pelayanan yang diberikan oleh pemandu kepada pengunjung.

\section{d.Assurance (Jaminan)}

Informasi yang disampaikan dapat dimengerti dan dipahami oleh pengunjung sebagai salah satu bentuk assurance atau jaminan bagi pengunjung dalam memperoleh informasi.pelayanan yang diberikan oleh pemandu memiliki kualitas yang baik yang dapat dilihat dari penyampaian informasi yang dapat dimengerti atau mudah dipahami oleh pengunjung Istana Kepresidenan Tampaksiring Bali. Hal ini menunjukkan bahwa pelayanan yang baik menekankan pada proses pemberian layanan tersebut.

\section{e. Emphaty (Empati)}


Kenyamanan dari pengunjung dalam mengunjungi Istana Kepresidenan Tampaksiring Bali merupakan salah satu tujuan pelayanan utama dan memberikan informasi yang lengkap dan jelas mengenai Istana Kepresidenan Tampaksiring Bali yang dapat menjadi tambahan wawasan dan pengetahuan bagi pengunjung. Kesesuaian antara apa yang telah disampaikan oleh pemandu dengan harapan pengunjung menunjukkan adanya empati (emphaty). Empati merupakan perhatian tulus yang diberikan oleh pemandu kepada pengunjung serta memberikan kenyamanan bagi pengunjung.

Pelayanan yang diberikan telah dilakukan dengan profesional dan berkualitas sehinbgga dapat menjadi tambahan refrensi informasi yang disampaikan kepada masyarakat. Kesediaan dari pemandu dalam menerima saran menunjukkan adanya sikap empati dari pemandu dengan memberikan kesempatan kepada pengunjung menyampaikan hal-hal yang harus dievaluasi untuk menjadi lebih baik. Berdasarkan uraian hasil penelitian dan pembahasan penelitian menunjukkan bahwa profesionalisme pemandu dalam meningkatkan pelayanan kunjungan istura di Istana Kepresidenan Tampaksiring Bali telah sesuai dengan SOP dan sesuai dengan Teori Pelayanan yang dibahas dalam penelitian ini.

Kendala Dari Profesionalisme Pemandu Dalam Meningkatkan Pelayanan Kunjungan Istura Pada Istana Kepresidenan Tampaksiring Bali

Profeisonalisme pemandu dalam meningkatkan pelayanan kunjungan istura pada Istana Kepresidenan Tampaksiring Bali telah berjalan dengan baik tetapi terdapat beberapa kendala yang harus diperhatikan sehingga mampu meningkatkan pelayanan kunjungan istura pada Istana Kepresidenan Tampaksiring Bali yaitu :

\section{- Kurangnya Jumlah Pemandu Jika Pengunjung Melebihi Kapasitas}

Pemandu merupakan pegawai yang memberikan informasi dan membantu pengunjung untuk mengunjungi dan memperoleh informasi yang berkaitan dengan Istana Kepresidenan Tampaksiring Bali. Pemandu telah berusaha bekerja secara maksimal tetapi masih terdapat kendala pada saat terdapat rombongan dalam jumlah besar. Masih terdapat kekurangan pemandu sehingga informasi yang disampaikan tidak maksimal kepada rombongan. Pemandu pada Istana Kepresidenan Tampaksiring Bali berasal dari staff subbagian rumah tangga dan protokol yang bertugas berdasarkan atas Keputusan Kepala Istana Kepresidenan Tampaksiring Bali Nomor 5 Tahun 2020. Jumlah pengunjung yang melebihi kapasitas ini terjadi apabila kunjungan tersebut adalah rombongan beberapa sekolah yang setiap rombongan terdiri dari puluhan orang sehingga membutuhkan pemandu yang lebih banyak. Masih kurangnya pemandu untuk memandu pengunjung. Sehingga dibutuhkan adanya pemandu tambahan agar informasi yang disampaikan 
menjadi lebih baik. Hal ini dapat diatasi dengan menambah jumlah pemandu sehingga pemberian pelayanan lebih efektif dan efisien. Selain itu pegawai bagian pendaftaran kunjungan istura sebaiknya melakukan penjadwalan dengan baik untuk menghindari penumpukan kunjungan sehingga jumlah kunjungan sebanding dengan jumlah pemandu dan pemberian pelayanan kunjungan pun menjadi lebih baik dan berkualitas.

\section{- Kurangnya Kemampuan Bahasa Asing Pemandu.}

Profesionalisme pemandu sangat dibutuhkan dalam melaksanakan tugas dan fungsi pokok sebagai pemandu. Tetapi tidak semua pemandu memiliki keterampilan dalam menggunakan bahasa asing, pemahaman penggunaan bahasa asing dapat menjadi kendala saat memandu wisatawan asing. Hal ini karena pemandu yang berasal dari staff subbagian rumah tangga dan protokol ini belum ada yang memiliki pendidikan terakhir Strata 1 Bahasa khususnya Bahasa Asing sehingga menjadi kendala dalam memberikan penjelasan dengan Bahasa Asing. Masih kurangnya kemampuan dari beberapa pemandu untuk menggunakan bahasa asing dalam memandu pengunjung luar negeri atau wisatawan asing sehingga menimbulkan kesulitan dalam berkomunikasi dengan wisatawan asing. Hal ini dapat diatasi dengan pemberian pendidikan dan pelatihan secara rutin kepada pemandu untuk menambah pengetahuan, wawasan dan keahlian pemandu dalam berbahasa asing dan menyampaikan informasi tentang Istana Kepresidenan Tampaksiring dalam memandu pengunjung.

\section{SIMPULAN}

Berdasarkan hasil analisis data dan pembahasan hasil penelitian di atas mengenai Profesionalisme Pemandu Dalam Meningkatkan Pelayanan Kunjungan Istura Pada Istana Kepresidenan Tampaksiring Bali dapat disimpulkan bahwa:

a. Profesionalisme pemandu dalam meningkatkan pelayanan kunjungan istura pada Istana Kepresidenan Tampaksiring Bali telah berjalan dengan baik sesuai dengan hasil analisis menggunakan Teori Pelayanan. Tetapi masih perlu dilakukan beberapa evaluasi, hal itu karena dari 5 indikator terdapat 1 indikator pelayanan yang harus dievaluasi yaitu perlunya penambahan sarana kebersihan sehingga tidak mengganggu kebersihan sebagai salah satu bentuk pendukung pelayanan. Sedangkan 4 indikator yang telah memenuhi yaitu adanya pemandu yang telah memiliki keterampilan dalam memandu, memandu dengan baik sehingga mudah dimengerti, memberikan kesempatan kepada pengunjung untuk bertanya serta memperhatikan kebutuhan informasi dari pengunjung. 
b. Kendala dari profesionalisme pemandu dalam meningkatkan pelayanan kunjungan istura pada Istana Kepresidenan Tampaksiring Bali adalah masih kurangnya jumlah pemandu dan masih kurangnya kemampuan pemandu dalam berbahasa asing.

\section{E. DAFTAR PUSTAKA}

Hasugian, Martha. 2017. Upaya Komunikasi Internal Dalam Meningkatkan Prestasi Kerja Pegawai Rumah Sakit Jiwa Daerah Atma Husada Mahakam. Jurnal Ilmu Komunikasi. Universitas Mulawarman. Vol 5, No 4, Hal 13-25.

Kurniawan, Agung. 2005. Transformasi Pelayanan Publik. Yogyakarta: Pembaharuan.

Moenir, H.AS. Manajemen Pelayanan Umum Di Indonesia. Jakarta : PT Bumi Aksara.

Parasuraman, Valarie A.Z and Berry. 2001. Delivery Service Quality. New York : Mc Millan

Siagian, Sondang. 2000. Manajemen Sumber Daya Manusia. Jakarta: PT Bumi Aksara

Sugiyono, 2017. Metode Penelitan Kuantitatifdan Kualitatif. Bandung: Alfabeta 